\title{
The Conundrum of Hedge Fund Definition
}

\author{
By
}

\author{
Hossein Nabilou*
}

\begin{abstract}
This Article attempts to define hedge funds and to distinguish them from a variety of similar investment funds. After reviewing the hedge fund definition in the U.S. and the EU, this Article argues that the current regulatory framework, which defines hedge funds by reference to what they are not rather than to what they are, is prone to regulatory arbitrage. Even in the presence of a statutory definition, due to the ineluctable indeterminacy of language and regulatory arbitrage problems, borderline issues will persist, which makes statutory definitions of hedge funds neither possible nor desirable. Therefore, regulators should avoid the temptation of proposing such statutory definitions. Instead, they should rely on regulatory discretion within a broad principles-based regulatory framework to do so.

For such a principles-based regulatory regime to work, regulators should rely on a functional definition of hedge funds. Accordingly, this Article defines hedge funds as privately organized investment vehicles with a specific fee structure, not widely available to the public, aimed at generating absolute returns irrespective of market movements (Alpha) through active trading and making use of a variety of trading strategies. This functional definition is likely to help address regulatory problems that might originate from statutory definitions of hedge funds.
\end{abstract}

Keywords: hedge fund, statutory definition, functional definition, regulatory arbitrage, principles-based regulation

JEL Classification: F3, G1, G2, G3, K2, N2

\footnotetext{
* Postdoctoral Researcher in Banking and Financial Law; Faculty of Law, Economics and Finance, University of Luxembourg; LL.M., University of Pennsylvania Law School; E-mail: hossein.nabilou@ uni.lu

The author is grateful to Alessio Pacces for his in-depth comments on earlier drafts of this paper.
} 


\section{Table of Contents}

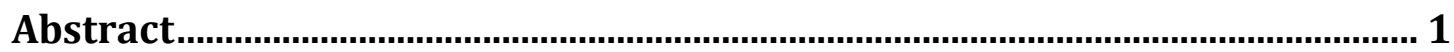

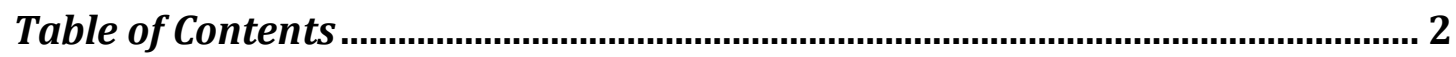

I. Introduction ............................................................................................ 3

II. The Statutory definitions of hedge funds in the U.S. and the EU............... 6

1. The U.S. hedge fund definition............................................................................6

1.1. The Investment Company Act of 1940 ……………………………………………..

1.2. Investment Advisers Act of 1940 ........................................................................... 10

1.3. Securities Act of 1933 ..................................................................................................... 11

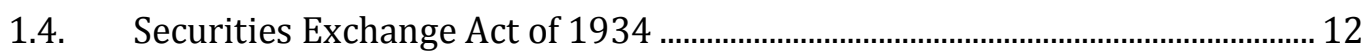

1.5. Dodd-Frank Act and elimination of the private adviser exemption ................13

2. The Definition of hedge funds in the EU............................................................16

III. Definitional problems and regulatory arbitrage ......................................20

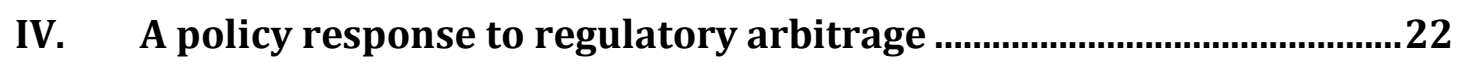

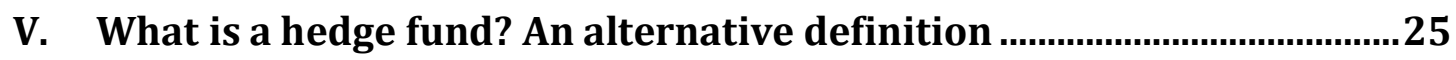

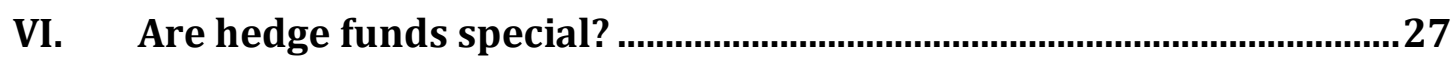

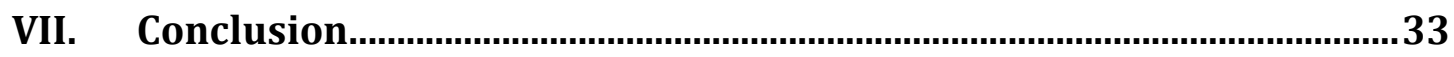




\section{Introduction}

Should you ask me to identify God or his nature, I shall cite Simonides as my authority: when the tyrant Hiero posed the same question to him, he asked for a day's grace to consider it privately, and when Hiero put the same question to him next day, he begged two days' grace. After doubling the number of days repeatedly, and being asked by Hiero why he did this, he answered: "The longer I ponder the question, the darker I think is the prospect of a solution." 1

In the aftermath of the global financial crisis, the quest to bring the hedge fund industry under official oversight, scrutiny, and regulation, gained substantial momentum. ${ }^{2}$ In addition, a chain of hedge fund-related events, which allegedly contributed to the collapse of a Large Complex Financial Institution (LCFI), ${ }^{3}$ buttressed the argument for government regulatory intervention in the hedge fund industry. ${ }^{4}$ Yet, deep in the theoretical underpinnings of this interventionist approach rest several fundamental and open-ended questions. One of the overlooked aspects of

\footnotetext{
${ }^{1}$ Cicero, The Nature of the Gods (Oxford University Press 1997) 23

${ }^{2}$ Even prior to the financial crisis there were considerable support for hedge fund regulation. For example, just one year before the financial market turmoil of the 2007, the Securities and Exchange Commission (SEC) Chairman, Christopher Cox, asserted that "[h]edge funds are not, should not be, and will not be unregulated". See Cox Christopher, Testimony Concerning the Regulation of Hedge Funds: Before the U.S. Senate Committee on Banking, Housing and Urban Affairs (2006)
}

In the EU, prior to the global financial crisis, the hedge fund industry was not regulated at the EU level. Instead, hedge funds were subject to regulations of the competent authorities of the Member States at the national level. See Phoebus Athanassiou, Hedge Fund Regulation in the European Union: Current Trends and Future Prospects (Kluwer Law International 2009). See also Commissions International Organization of Securities, The Regulatory Environment for Hedge Funds, A Survey and Comparison, Final Report, 2006).

However, even at that time, there were concerns about hedge funds' role in financial markets and especially in the corporate governance of non-financial companies. Perceived as the legacy of the American laissez-faire capitalism, hedge funds attracted considerable animosity from politicians of continental Europe. Calling for their abolition, hedge funds were demonized as being 'crazy' and 'hellish' which "fall like a plague of locusts" over the companies, "devour everything, then fly on to the next one". (A statement quoted from Franz Müntefering, Germany's deputy chancellor) See Sebastian Mallaby, 'Hands off hedge funds' (2007) 86 Foreign Affairs 91 92. Not to fall behind in the race to demonization of hedge funds, others called hedge funds along with private equity firms " "aggressive' gangs of 'speculators', bent on "snapping up firms, sacking workers and creaming off profits". See, Battle of the Big Beasts: Mutual Suspicions and National Interests Underlie European Rows over Financial Regulation (2009) ${ }^{3}$ This happened in 2007 when Bear Stearns and Goldman Sachs injected capital to their ailing hedge funds. Although it is argued that a banking entity has nothing to gain from a below-market transfer of credit to a troubled affiliate, (Daniel R. Fischel, Andrew M. Rosenfield and Robert S. Stillman, 'The Regulation of Banks and Bank Holding Companies' (1987) 73 Virginia Law Review 301 326), the bailouts of hedge funds by their parent companies (banking entities) in the recent financial crisis proved otherwise. For example, the Bear Stearns, Goldman Sachs, and Citigroup bailed out their internal hedge funds just before their collapse. It is generally believed that these bailouts contributed to the collapse of Bear Stearns, a systemically important financial institution. See Darrell Duffie, 'The Failure Mechanics of Dealer Banks' (2010) 24 The Journal of Economic Perspectives 51 59. See also Michael R. King and Philip Maier, 'Hedge Funds and Financial Stability: Regulating Prime Brokers Will Mitigate Systemic Risks' (2009) 5 Journal of Financial Stability 283291.

${ }^{4}$ For example, in the run-up to the recent financial crisis, the collapse of two Bear Stearns' hedge funds in the spring of 2007 imposed substantial losses on the parent company, itself a systemically important investment bank. In that case, the collapse of hedge funds did not impose a substantial credit risk on Bear Stearns. However, Bear Stearns bailed them out due to reputational concerns that the failure of such entities could raise concerns about the safety and soundness of the firm itself. Such a bailout highlighted the concerns about the indirect subsidization of hedge funds by taxpayers through the parent organization's access to the Federal Reserve discount window and implicit guarantee of a bailout of a too-big-to-fail parent company. Such an opportunity for excessive risk taking means that hedge fund managers do not bear the entire costs and consequences of their risk taking, implying that regulatory measures are needed to internalize those externalities. See Dixon Lloyd, Noreen Clancy and Krishna B. Kumar, Hedge Funds and Systemic Risk (RAND Corporation 2012) 43 
hedge funds, which furtively slipped under the regulatory radar, was the definitional challenge lying at the heart of the hedge fund regulation debate.

'Private funds', 'alternative investment funds', 'hedge funds', and a panoply of more designations in different languages represent the nomenclature used to refer to a type of investment fund having idiosyncratic attributes that distinguishes it from mainstream investment funds. Although the term 'hedge fund' was coined by Carol J. Loomis in an article of 1966, which discussed the structure and investment strategies of the investment vehicle originally created in 1949 by Alfred W. Jones, ${ }^{5}$ thus far, there is no clear understanding of the term. Indeed, questions about the definition of hedge funds can confuse even the savviest and most discerning veterans of the hedge fund industry, let alone laymen and the uninitiated.

Hedge funds have been and will continue to be a murky phenomenon, not least due to the dynamic nature of their business, the complexity of their legal structure, the vast variety of investment strategies at their disposal, and the lower levels of public disclosure required of them. The nebula surrounding the hedge fund industry, which is also partly rooted in definitional problems, poses major challenges for the regulatory strategies intended to address the problems that allegedly contributed to the global financial crisis. The most conspicuous of these challenges is regulatory arbitrage, whose basic raison d'etre is to sever the link between the economic substance of an activity and its legal treatment. ${ }^{6}$

The definitional challenges in regulating hedge funds are neither academic, ivory-tower fantasies, nor inconsequential, linguistic hair-splitting. Indeed, the relatively short history of hedge fund regulation has already witnessed cases whose outcomes were, at least partially, dependent on the definition of the term 'hedge fund' ${ }^{7}$ The definitional problems, which often lead to boundary problems ${ }^{8}$ and questions of the applicability of specific rules and regulations, are so deeply ingrained in the hedge fund-regulation debate that legislators and regulators simply sweep the definitional issues under the rug to avoid having to define hedge funds. ${ }^{9}$

\footnotetext{
${ }^{5}$ Carol J. Loomis, 'The Jones nobody keeps up with' (1966) 4 Fortune Magazine

${ }^{6}$ Victor Fleischer, 'Regulatory arbitrage' (2010) 89 Texas Law Review 227229

${ }^{7}$ See Goldstein v. SEC, 451 F.3d 873 (D.C. Cir. 2006).

${ }^{8}$ The boundary problem denotes a situation in which there is a substitution flow of financial activities towards lessregulated activities when the costs of 'effective regulations' make the regulated activities costlier and hence less profitable. See Charles Goodhart, 'The Boundary Problem in Financial Regulation' (2008) 206 National Institute Economic Review 48. See also Charles A. E. Goodhart and Rosa M. Lastra, 'Border Problems' (2010) 13 Journal of International Economic Law 705

${ }^{9}$ However, for the purposes of the Form PF, the SEC recently defined hedge funds in terms of their performance fee, high leverage, and short selling. See Commission Commodity Futures Trading, Securities and Commission Exchange, 'Reporting by Investment Advisers to Private Funds and Certain Commodity Pool Operators and Commodity Trading Advisors on Form PF' (2011) 22
} 
Since the complexity and dynamics of financial institutions do not lend themselves to a per genus et differentiam definition, ${ }^{10}$ the search for an all-encompassing definition that is adequately inclusive and sufficiently exclusive of each and every aspect of hedge funds seems to be a futile endeavor. ${ }^{11}$ However precise a definition of hedge funds may be, ineluctable borderline issues will always remain. ${ }^{12}$ Therefore, it is not surprising that a consistent pattern of avoidance - that is, a refusal to engaging in definitional issues in hedge fund regulation can be observed among regulators. Against this backdrop, the purpose of this Article is to provide a working definition of hedge funds by which regulators can distinguish hedge funds from other similar investment funds within a principles-based regulation framework, that is, an approach to regulation that is focused on 'goals' and 'outcomes' rather than the 'means' used to achieve those goals. ${ }^{13}$

This Article first reviews the definition of hedge funds in the two largest hedge fund-regulatory jurisdictions (i.e., the U.S. and the EU). Second, it highlights the potential problems that might arise from statutory definitions of hedge funds and argues why such definitions can be counterproductive and are likely to give rise to regulatory arbitrage. Third, this Article focuses on the public-policy responses to regulatory arbitrage stemming from definitional problems and proposes that, to counter regulatory arbitrage by hedge funds, any definition of hedge funds should reflect the realities of the dynamic and vibrant hedge fund industry. To achieve that objective, this Article advocates a principles-based regulatory framework, within which regulators are afforded sufficient power to designate an investment fund as a 'hedge fund' if they find that certain functional criteria are met thereby, even though the entity itself uses different self-designating labels. At the end, this Article presents a functional definition of hedge funds, based not only on their organizational structure, but also on the sui generis role they play in financial markets. The article also expands on this definition by focusing on specific functions of hedge funds and the features that mark them as special in financial market.

\footnotetext{
${ }^{10}$ This is an Aristotelian pattern of definitions in which definitions are provided by determining their genus to which that term belongs and then providing the difference which gives the species and locates the term within that genus. The most famous example is humans are rational animals.

${ }^{11}$ Since definitions define boundaries between financial institutions imperfectly, it is argued that the future of securities regulation is likely to be about the resolution of the boundary questions. See Joel Seligman, 'The Obsolescence of Wall Street: A Contextual Approach to the Evolving Structure of Federal Securities Regulation' (1995) 93 Michigan law review 649 651. Although that statement is made in the context of U.S. Federal securities laws and their relationship with state securities laws (blue-sky laws), and boundaries between those laws, such a statement equally holds in the debate about hedge fund regulation.

${ }^{12}$ See H. L. A. Hart, The Concept of Law, vol 2 (Oxford University Press 1994) 13. It is also argued that the laws resting upon definitions and criteria involving clear rules and thresholds are prone to legal engineering and regulatory arbitrage. See Doreen McBarnet, 'Financial Engineering or Legal Engineering? Legal Work, Legal Integrity and the Banking Crisis' in Iain G. MacNeil and Justin O'Brien (eds), The Future of Financial Regulation (The Future of Financial Regulation, Hart Publishing 2010) 72

${ }^{13}$ Authority Financial Services, Principles-based regulation: Focusing on the outcomes that matter, 2007) See also Julia Black, Martyn Hopper and Christa Band, 'Making a success of Principles-based regulation' (2007) 1 Law and financial markets review 191192
} 
Such a focus may well help regulators to better understand and identify the hedge fund business and eventually prevent hedge funds from engaging in regulatory arbitrage.

\section{The Statutory definitions of hedge funds in the U.S. and the EU}

Given that both the U.S. and the EU defined hedge funds by reference to what they are not rather than by reference to what they are, to investigate their definitions of hedge funds, the focus should not be on the hedge fund entity itself; rather, special attention must be paid to other, relatively well-known and defined financial institutions. Only by first studying nonhedge-fund financial institutions and investment funds, and then engaging in a process of elimination, is it feasible to understand what hedge funds are. Due to the fact that such a definition of hedge funds is embedded in a complex web of financial regulations in the U.S., doing so requires going through a maze of financial regulations. In other words, a negative definition of hedge funds implies that, in order to define and understand hedge funds, a survey of the existing regulations that, by design, exclude hedge funds is required. In short, understanding what hedge funds are not calls for an overview of the hedge fund regulatory framework that existed prior to the Dodd-Frank Act. The following section studies the four main U.S. legislative Acts that relate to hedge funds: the Investment Company Act of 1940, the Investment Advisers Act of 1940, the Securities Act of 1933, and the Securities Exchange Act of 1934, before discussing the Dodd-Frank Act. The Article immediately thereafter clarifies the definition of hedge funds set forth in the EU's Alternative Investment Fund Managers Directive (AIFMD).

\section{The U.S. hedge fund definition}

Prior to the regulatory reforms adopted in the wake of the global financial crisis, the U.S. had no statutory definition of hedge funds. ${ }^{14}$ This regulatory lacuna gave rise to a peculiar, negative definition of hedge funds; essentially, hedge funds became the product of statutory and regulatory carve-outs that were negatively defined by reference to what they were not, rather

\footnotetext{
${ }^{14}$ However, the U.S. Private Fund Investment Advisers Registration Act of 2010 (the Private Fund Act) introduces the concept of 'private fund' a subcategory of which can be a hedge fund. In fact, the Private Fund Act follows the path of its predecessors and defines hedge funds by reference to what they are not, rather than to what they are. 12 U.S.C. $\$ 1851(\mathrm{~h})(2)$. However, the Private Fund Act and the EU Alternative Investment Fund Managers Directive's (AIFMD) definitions are criticized for failing to create a clear distinction between hedge funds and other similar funds such as private equity funds. See Jennifer Payne, 'Private Equity and Its Regulation in Europe' (2011) 12 European Business Organization Law Review 559584

See also Jacob Rothschild, 'Europe is Getting It Wrong on Financial Reform ' Financial Times (<http://www.ft.com/cms/s/0/f51bdb9a-4caa-11df-9977-00144feab49a.html\#axzz2JvN8jQ2M> accessed April 20
} 
than to what they were. ${ }^{15}$ To be more precise, prior to the Dodd-Frank Act, U.S. financial regulation purposefully 'designed out' certain entities from regulatory oversight by the Securities and Exchange Commission (SEC). In other words, prior to the U.S.'s 2010 financialregulatory overhaul, hedge funds were - by design - exempt from the majority of the regulations normally applicable to investment companies. ${ }^{16}$

The regulatory failure to define hedge funds by no means suggests that there had not been attempts to provide a legal definition of hedged funds. Given the case law's constant exposure to the ever-changing world of finance, U.S. courts developed a jurisprudential definition of hedge funds. In Goldstein v. SEC., the U.S. Court of Appeals for the District of Columbia stated:

\begin{abstract}
'Hedge funds' are notoriously difficult to define. The term appears nowhere in the federal securities laws, and even industry participants do not agree upon a single definition. The term is commonly used as a catch-all for 'any pooled investment vehicle that is privately organized, administered by professional investment managers, and not widely available to the public'. ${ }^{17}$
\end{abstract}

As even those with very little exposure to, or experience with, the hedge fund industry can see, the court's definition is far from satisfactory. The following subsections present an overview of the U.S.'s regulatory attempt to define hedge funds, both before and after the Dodd-Frank Act, including an overview of the above mentioned Acts, to help clarify the U.S.'s definition of hedge funds.

\title{
1.1. The Investment Company Act of 1940
}

The Investment Company Act of 1940 regulates publicly owned companies that invest in securities (i.e., investment companies), in contrast to industrial companies that engage in manufacturing goods or providing services. This Act mostly regulates mutual funds and their managers, directors, and advisers. As with other regulations in financial markets, this Act first requires investment companies to register with the SEC. Further, it imposes certain requirements on their capital structure and their transactions with insiders and institutes certain restrictions on the types of transactions such registered investment companies can enter into.

\footnotetext{
${ }^{15}$ Goldstein v. SEC, 451 F.3d 873, 884 (D.C. Cir. 2006). See also Gordon De Brouwer, Hedge Funds in Emerging Markets (Cambridge University Press 2001) 10

${ }^{16}$ Nevertheless, hedge funds were not totally exempt from those regulations. As this article will demonstrate, there was a whole host of other applicable rules and regulations such as Securities Exchange Act's anti-fraud liability under $\S 10(\mathrm{~b})$ and the well-known SEC's rule 10b-5.

${ }^{17}$ A statement by Judge Randolph, Circuit Judge, in Goldstein v. SEC. See Goldstein v. SEC, 451 F.3d 873, 884 (D.C. Cir. 2006).
} 
Normally, because hedge funds are investment companies as defined by the Investment Company Act, ${ }^{18}$ they would fall under the Act's ambit. Nevertheless, the Act establishes two exemptions from its provisions. First, section 3(c)(1) of the Investment Company Act exempts investment companies that have no more than one hundred investors; and second, section 3(c)(7) of the National Securities Markets Improvement Act (NSMIA) exempts such investment companies composed of an unlimited number of qualified purchasers. Provided that an investment company complies with the requirements of either of the two exemptions, they are relieved of the obligation to register with the SEC.

Section 3(c)(1) $)^{19}$ provides that "any issuer whose outstanding securities (other than short-term paper) are beneficially owned by not more than one hundred persons and which is not making and does not presently propose to make a public offering of its securities" is not deemed to be an 'investment company'. ${ }^{20}$ In other words, a fund or an issuer having fewer than one hundred investors that raises capital through private placement is not considered an investment company for the purposes of the Investment Company Act and, accordingly, is exempt from the registration requirement.

In a 1996 no-action letter, ${ }^{21}$ the SEC agreed that "each Fund may be considered a single beneficial owner of a 3(c)(1) Entity, provided that:

1. no Fund will invest in any 3(c)(1) Entity to the extent that the attribution provisions of section 3(c)(1)(A) are triggered; and

2. no Fund or 3(c)(1) Entity will be structured or operated for the purpose of circumventing the provisions of the Act." 22

Therefore, in accordance with the above-cited provisions and the SEC's no-action letter, beneficial ownership by a 'company' was considered to be beneficial ownership of one person, such that section 3(c)(1) issuers could have fewer than one hundred funds as their investors,

\footnotetext{
${ }^{18}$ According to the Investment Company Act an 'investment company' means "any issuer which--

(A) is or holds itself out as being engaged primarily, or proposes to engage primarily, in the business of investing, reinvesting, or trading in securities; (B) is engaged or proposes to engage in the business of issuing face-amount certificates of the installment type, or has been engaged in such business and has any such certificate outstanding; or (C) is engaged or proposes to engage in the business of investing, reinvesting, owning, holding, or trading in securities, and owns or proposes to acquire investment securities having a value exceeding 40 per centum of the value of such issuer's total assets (exclusive of Government securities and cash items) on an unconsolidated basis." 15 U.S.C. $\S 80 \mathrm{a}-3(\mathrm{a})(1)$.

19 15 U.S.C. $\$ 80 \mathrm{a}-3(\mathrm{c})(1)$.

${ }^{20} 15$ U.S.C. $\$ 80 \mathrm{a}-3(\mathrm{c})(1)(\mathrm{A})$.

${ }^{21}$ Facing uncertainty with respect to whether a particular product, service, or action would constitute a violation of the federal securities law, an individual or entity may request a 'no-action' letter from the SEC staff. A no-action letter is the SEC's staff position letter stating that if certain conditions are met, the staff will recommend no enforcement action be taken by the SEC against the requester based on the representations in the request. The no action letters only represent the opinion of the SEC's staff and not those of the SEC's commissioners. See Stephen J. Choi and A. C. Pritchard, Securities Regulation: Cases and Analysis, vol 2 (Thompson/Foundation Press 2008) 41

${ }^{22}$ Cornish \& Carey Commercial, Inc., SEC No-Action Letter (pub. avail. June 21, 1996).
} 
provided that the ownership of the shares by any one of those companies or persons does not exceed 10 percent of the outstanding voting securities of the issuer.

In a 1994 no-action letter, ${ }^{23}$ the SEC announced that if the employee participants of a definedcontribution plan involved in investment decision making, that plan could not be counted as a single investor. Therefore, if participants in such a contribution plan have an active role in the management of the plan, each participant would be counted towards the 100 -investor limit.

Later, on October 11, 1996, the National Securities Markets Improvement Act (NSMIA) became law. That Act amended, inter alia, the Investment Company Act and the Investment Advisers Act of 1940. Its significance lies in its amendments, which are of particular relevance to hedge funds and their ability to raise funds from an unlimited number of qualified purchasers. Section 3(c)(7) of the NSMIA (codified as section 3(c)(7) of the 1934 Act, as amended) states that hedge funds can offer their securities to an unlimited number of 'qualified purchasers' ${ }^{24}$ In other words, this Act created new categories of hedge funds that could be sold to an unlimited number of 'qualified purchasers'. Nonetheless, section 12(g) of the Securities Exchange Act of $1934^{25}$ continued to set a limit on the number of hedge funds' qualified investors. According to that Act, if a fund has 500 or more investors, qualified or not, the registration and reporting requirements of the Securities Exchange Act apply. Thus, to be exempt from Securities Exchange Act regulations, hedge funds needed to limit the number of their investors to $499 .{ }^{26}$

Pursuant to the enactment of the NSMIA, two types of hedge funds emerged, 'Section 3(c)(1) funds' and 'Section 3(c)(7) funds'. Basically, subject to certain requirements, the NSMIA allowed funds that relied on the definitional exception of the Investment Company Act section 3(c)(1) ('Section 3(c)(1) funds') (i.e., privately held investment companies with 100 or fewer beneficial owners), to convert into 'Section 3(c)(7) funds' (i.e., privately held investment companies owned solely by qualified purchasers). As long as a hedge fund falls within either of these two exemptions, it will not be considered an investment company for the purposes of the Investment Company Act and its strict provisions would not apply.

\footnotetext{
${ }^{23}$ PannAgora Group Trust, SEC No-Action Letter, (pub. avail. Apr. 29, 1994).

${ }^{24}$ A 'Qualified purchaser' means (i) any natural person who owns not less than $\$ 5$ million in investments; (ii) any company that owns not less than $\$ 5$ million in investments and that is owned directly or indirectly by close family members; (iii) any trust, which is not formed for investment purposes, with no less than $\$ 5$ million in investment; or (iv) any investment manager or company, which owns and invests not less than $\$ 25$ million in investments. See 15 U.S.C. $\S 80 \mathrm{a}-2(\mathrm{a})(51)(\mathrm{A})$.

2515 U.S.C. $§ 78(1)(\mathrm{g})$.

${ }^{26}$ François-Serge Lhabitant, Handbook of Hedge Funds (John Wiley \& Sons, Ltd. 2006) 55
} 


\subsection{Investment Advisers Act of 1940}

According to the Investment Advisers Act, ${ }^{27}$ an 'investment adviser' means "any person who, for compensation, engages in the business of advising others, either directly or through publications or writings, as to the value of securities or as to the advisability of investing in, purchasing, or selling securities, or who, for compensation and as part of a regular business, issues or promulgates analyses or reports concerning securities". ${ }^{28}$ The Act requires registration with the SEC and establishes disclosure obligations, restrictions on fee arrangement structures and other obligations with regard to maintaining books and records for those advisers falling under its regulatory purview.

Hedge fund advisers clearly fall within that definition, which implies that they should be obliged to register with the SEC and comply with its regulations. Nevertheless, hedge funds could avoid that obligation by taking advantage of the Act's section 203(b) de minimis exception. Section 203(b)(3) ${ }^{29}$ of the Investment Advisers Act states that an investment adviser having fewer than 15 clients during the course of preceding 12 months, "who neither holds himself out generally to the public as an investment adviser nor acts as an investment adviser to any investment company" need not register with the SEC. ${ }^{30}$ Moreover, a hedge fund adviser can take advantage of the Investment Advisers Act's safe harbor, which provides that a legal entity, such as a hedge fund, is to be counted as a single client. Therefore, if a hedge fund adviser advises fewer than fifteen individual funds over the course of a rolling twelve-month period, that adviser would have been be exempt from registration. Accordingly, the de minimis exception and the SEC's interpretation of the word 'client,' which included legal entities such as hedge funds, each hedge fund adviser could have 14 funds as clients. It is worth remembering that each of those hedge fund clients, in turn, could have up to 499 individual investors. ${ }^{31}$

In 2004, the SEC, concerned about hedge fund secrecy and fraudulent practices, as well the need to rein in hedge fund advisers and protect unsophisticated investors who had indirectly invested in hedge funds through pension funds and other financial institutions, issued a new rule (commonly known as 'the Hedge Fund Rule'). ${ }^{32}$ Basically, in this rule making, the SEC announced that the term 'client' includes 'investors', and in the assessment of the number of clients an adviser had, all investors in the investing fund, including individual investors, must be counted. Thus, for the next two years, the SEC required hedge fund investment advisers with

\footnotetext{
2715 U.S.C. $\$ 80 b-1(21)$.

${ }^{28} 15$ U.S.C. $\$ 80 \mathrm{~b}-2(\mathrm{a})(11)$.

${ }^{29} 15$ U.S.C. $\$ 80 \mathrm{~b}-3(\mathrm{~b})(3)$.

${ }^{30}$ See 15 U.S.C. $\$ 80 b-3(b)(3)$.

${ }^{31}$ Thus hedge fund clients can potentially grow up to 6,986 individuals. See Wulf A. Kaal, 'Hedge Fund Regulation via Basel III' (2011) 44 Vanderbilt Journal of Transnational Law 389414

${ }^{32}$ Securities United States and Commission Exchange, Registration under the Advisers Act of Certain Hedge Fund Advisers (2004)
} 
more than 15 clients (regardless of whether they were individuals or legal entities) to register with it under the Investment Company Act. Nevertheless, in 2006, the U.S. Court of Appeals for the District of Columbia in Goldstein v. SEC ${ }^{33}$ found the rule arbitrary and vacated it. Ultimately, new legislation, in the form of the Private Fund Investment Advisers Registration Act (hereinafter, the Private Fund Act), ${ }^{34}$ eliminated the 15 -client exemption. ${ }^{35}$

\subsection{Securities Act of 1933}

Financial services and products, particularly securities, are deemed to be credence goods. ${ }^{36}$ The information asymmetry in credence goods is wider than all other types of information-sensitive goods and services. Historically, information sensitivity and the existence of such a huge information asymmetry between issuers and investors have frequently caused market failures in securities markets and, hence, frequent disruptions in market liquidity. In response to market disruptions and with a view toward minimizing asymmetric information between issuers and investors in publicly traded companies in primary market transactions, the US enacted the Securities Act of 1933, which imposes registration and disclosure obligations on the issuers of regulated securities. The Act's main objective is to ensure informed investment decisions by investors, by requiring issuers to disclose all relevant information concerning the value of the securities to be issued, thereby preventing fraud in the primary markets.

Since interests in hedge funds are deemed 'securities' for purposes of the Securities Act of $1933^{37}$ as interpreted by the courts, including the definition and meaning of a 'security' (i.e.,

\footnotetext{
${ }^{33}$ Goldstein v. SEC, 451 F.3d 873, 884 (D.C. Cir. 2006). The court basically argued that the regulatory obligations of the advisers are owed to the funds rather than to the clients of the funds. Such a decision is criticized on the ground that the primary focus of regulation should be on the intermediated investors- those who put their investment in the fund- rather than on the funds themselves. Such an approach proposes that the advisers to private funds should owe their regulatory obligations to both the funds and the investors in the funds. See Anita K. Krug, 'Institutionalization, Investment Adviser Regulation, and the Hedge Fund Problem' (2011) 63 Hastings Law Journal 11

${ }^{34}$ The Private Fund Act is the Title IV of the Dodd-Frank Act, which involves the "Regulation of Advisers to Hedge Funds and Others" the short title of which is the "Private Fund Investment Advisers Registration Act of 2010" (the Private Fund Act). The primary purpose of this title is to change the investment adviser registration and exemption regime under the Advisers Act of 1940 and impose registration and reporting requirement on hedge funds and private equity funds.

${ }^{35}$ This decision of the court is practically repealed by the Dodd-Frank Act.

${ }^{36}$ In economic theory, with respect to informational imperfections, product and services are categorized into three broad groups. 'Search goods', the quality of which can be inspected upon purchase; 'Experience goods' the quality of which can only be assessed after the purchase and the use of those goods (or services); and 'Credence goods' the quality of which cannot be assessed even after purchase and use, or whose quality might not be assessable at all. See Philip Nelson, 'Information and Consumer Behavior' (1970) 78 Journal of Political Economy 311

Market forces cannot effectively discipline the suppliers of the credence goods, and there is a significant likelihood of the market failure resulting in the 'lemons problem'. See George A. Akerlof, 'The Market for "Lemons": Quality Uncertainty and the Market Mechanism' (1970) 84 The Quarterly Journal of Economics 488

Most of the financial products and services are considered credence goods whose quality is not ascertainable even after the purchase. See Alessio M. Pacces and Heremans Dirk, 'Regulation of Banking and Financial Markets"' in Alessio M. Pacces and R. J. Van den Bergh (eds), Forthcoming in 'Regulation and Economics' in Encyclopedia of Law and Economics, vol 2 (Forthcoming in 'Regulation and Economics' in Encyclopedia of Law and Economics, Elgar 2011) 9. See also Alessio Pacces, 'Financial Intermediation in the Securities Markets: Law and Economics of Conduct of Business Regulation' (2000) 20 International Review of Law and Economics 479

${ }^{37} 15$ U.S.C. $\$ 77 b(a)(1)$.
} 
the Howey test) ${ }^{38}$ no public solicitation of such securities is allowed unless the issuer is registered with the SEC and complies with all of the 1933 Act's reporting and other requirements. Hedge funds, like any other investment fund, might fall within the scope of the Securities Act of 1933 if they offer investment opportunities to investors in an initial offering, unless they qualify for one of the exemptions set out in the Act.

The 1933 Act furnished a private-offering exemption in its section 4(2). ${ }^{39}$ If an issuer met the requirements of a private offering, it did not need to comply with the requirements of the Act with regard to information disclosure. Alternatively, an issuer could rely on the safe harbor provided by Rule 506 of Regulation D. ${ }^{40}$ This rule allowed securities to be privately offered "to a maximum of 35 sophisticated purchasers and an unlimited number of 'accredited investors' as defined by Rule 501(a) of the 1933 Act." ${ }^{41}$

\subsection{Securities Exchange Act of 1934}

The Securities Exchange Act of 1934, as amended, regulates secondary market transactions and all institutions participating in such transactions, including market professionals and institutions. This Act was intended to enhance the efficiency of trading through national securities markets. It also protects investors primarily through disclosure obligations. It requires, inter alia, brokers, national securities exchanges, and municipal securities dealers to register with the SEC and comply with its extensive regulations. It further requires continuous disclosure through periodic reporting requirements (i.e., quarterly and annual reporting by publicly traded companies) commonly known as 'Exchange Act reporting issuers'. This Act only regulates post-distribution or secondary market trading such as tender offers, insider trading, and proxy solicitations. Registered investment funds under this Act are subject to:

1. Periodic disclosure requirements under $\S 13^{42}$ and $\S 13(\mathrm{~d}), \S 13(\mathrm{~g})$, and $\S 13(\mathrm{f})$;

2. Proxy rules under $\$ 14 ;{ }^{43}$

3. Insider reporting requirements; and

4. Short-swing profits transaction rules under $\$ 16 .{ }^{44}$

In addition to the above-mentioned requirements, this Act imposes the most important and the most inclusive anti-fraud liability under its $\S 10($ b), which is supported by the SEC's well-

\footnotetext{
${ }^{38}$ SEC v. W. J. Howey Co., 328 U.S. 293, 301 (1946).

3915 U.S.C. $\$ 77 \mathrm{~d}(2)$.

${ }^{40}$ Regulation D, 17 C.F.R. 230.506.

${ }^{41} 17$ C.F.R. 230.501

42 15 U.S.C. $\$ 78 \mathrm{~m}$.

${ }^{43} 15$ U.S.C. $\$ 78 \mathrm{n}$.

${ }^{44} 15$ U.S.C. $\$ 78 \mathrm{p}$.
} 
known Rule 10b-5. The Securities Exchange Act also contains anti-manipulation provisions and rules regulating proxy solicitation and certain relevant disclosures.

The Securities Exchange Act generally applies to brokers and dealers and since most hedge funds were considered traders rather than dealers, ${ }^{45}$ this Act's section $15 \mathrm{~b}$ registration requirement did not apply to them. However, if a hedge fund took on dealer functions, ${ }^{46}$ it should have been registered under this Act. ${ }^{47}$ Since most hedge funds do not issue securities to be listed on a securities exchange, they do not fall under the scope of the Securities Exchange Act and within its definition of 'dealer in securities'.

In addition, section 12(g) of the Securities Exchange Act required an issuer having 500 or more total investors and assets in excess of one million dollars to register with the SEC. However, hedge funds limited the number of their total investors to 499, thereby avoiding such registration and reporting requirements. Nevertheless, the antifraud provisions of the Securities Exchange Act $(\$ 10 \mathrm{~b})^{48}$ and SEC's Rule $10 \mathrm{~b}-5$ apply to all investment companies regardless of whether or not it is registered.

\subsection{Dodd-Frank Act and elimination of the private adviser exemption}

Section 402 of the Private Fund Act, characterizes hedge funds as 'private funds' under the Investment Advisers Act, which regulates investment advisers who advise and manage investment funds in the U.S. In addition to imposing registration and reporting requirements, the Act imposes substantive regulatory requirements on investment advisers. Under the previous regime, which was repealed by the Private Fund Act, the Investment Advisers Act excluded certain investment advisers from the application of its requirements; ${ }^{49}$ Under that regime, hedge fund advisers were exempt from registration as long as they advised no more than 15 clients ('the Private Adviser Exemption'). Section 203(b)(3) of the Investment Advisers Act, which was amended by the Dodd-Frank Act, no longer exempts advisers with such qualifications.

\footnotetext{
${ }^{45}$ Securities United States and Commission Exchange, Implications of the Growth of Hedge Funds: Staff Report to the United States Securities and Exchange Commission, 2003) 14. Title 15 U.S.C. § 78c(a)(5)(A) defines a dealer as "any person engaged in the business of buying and selling securities (not including security-based swaps, other than security-based swaps with or for persons that are not eligible contract participants) for such person's own account through a broker or otherwise."

${ }^{46}$ Mehrling argues that although Long Term Capital Management (LTCM) was legally a hedge fund, it effectively engaged in dealer functions. See Perry Mehrling, 'Minsky and Modern Finance: The Case of Long Term Capital Management' (2000) 26 The Journal of Portfolio Management 81

${ }^{47}$ Indeed, some hedge funds opted to register as dealers under the Exchange Act. See United States and Exchange, Implications of the Growth of Hedge Funds: Staff Report to the United States Securities and Exchange Commission 4815 U.S.C. $§ 78 \mathrm{j}(\mathrm{b})$.

${ }^{49}$ However, it is maintained that these exclusions do not mean that antifraud liability and certain other provisions do not apply to hedge funds.
} 
The Investment Company Act of 1940 defines a 'private fund' to be an issuer that would be an investment company, as defined in its section 3 of the Investment Company Act ${ }^{50}$ unless the issuer could avail itself of an exemption under sections 3(c)(1) or 3(c)(7) thereof. Section $3(c)(1)$ is only available to a fund that does not publicly offer its securities and has no more than 100 beneficial owners of its outstanding securities, while section 3(c)(7) is only available to a fund that does not publicly offer its securities and limits its owners to qualified purchasers.

The Private Fund Act only requires managers acting solely as an adviser to private funds with $\$ 150$ million or more in assets under management (AUM) ${ }^{51}$ to register with the SEC. ${ }^{52}$ Therefore, for the managers whose AUM exceeds the $\$ 150$ million threshold, For those managers, the Act abolishes the private investment adviser exemption found in the Investment Advisers Act as interpreted by the Goldstein v. SEC decision. ${ }^{53}$ An adviser, who is not registered with the SEC, is required, however, to register with the State in which it has the principal office if the State's law so requires. In short, under the new rules, unless private fund advisers have at least $\$ 150$ million in AUM, they are not required to register with and report to the SEC. ${ }^{54}$

The Volcker Rule uses the Private Fund Act's definition of a hedge fund. Under the Volcker Rule, a hedge fund or private equity fund is an issuer that would be an investment company, as defined in the Investment Company Act of $1940,{ }^{55}$ but for section 3(c)(1) or 3(c)(7) of that Act, or such similar funds as the appropriate federal banking agencies, the SEC, and the Commodity Futures Trading Commission (CFTC) may determine. ${ }^{56}$ Therefore, hedge funds and private equity funds are defined to include any issuer that relies on the exemptions of the definition of investment company under sections 3(c)(1) or 3(c)(7) of the Investment Company Act. ${ }^{57}$ According to the Investment Company Act "an issuer that is not making and does not presently propose to make a public offering of its securities and either (i) has outstanding securities that are beneficially owned by not more than one hundred persons or (ii) has outstanding securities that are owned exclusively by qualified purchasers" is excluded from the definition of 'investment company'. ${ }^{58}$ The definitional exclusions set out in the Investment Company Act, as amended, are used by hedge funds and a large number and variety of other legal entities. These other entities include special purpose acquisition vehicles, certain ERISA-qualified

\footnotetext{
5015 U.S.C. $80 \mathrm{a}-3$.

${ }^{51}$ The total market value of the assets managed by an investment company on behalf of its investor is called AUM.

5215 U.S.C. $\S 80 b-3(\mathrm{~m})(1)$.

${ }^{53}$ Goldstein v. SEC, 451 F.3d 873 (D.C. Cir. 2006).

${ }^{54} 15$ U.S.C. $\$ 80 \mathrm{~b}-3(\mathrm{~m})(1)$.

5515 U.S.C. $80 \mathrm{a}-1$ et seq.

${ }^{56} 12$ U.S.C. $\$ 1851(\mathrm{~h})(2)$.

${ }^{57}$ Financial Stability Oversight Council, Study \& Recommendations on Prohibitions on Proprietary Trading \& Certain Relationships with Hedge Funds and Private Equity Funds (2011) 57

${ }^{58} 15$ U.S.C. $\$ 80 \mathrm{a}-3(\mathrm{c})$.
} 
employee pension funds, controlled subsidiaries, and certain joint ventures and, perhaps, venture capital funds. ${ }^{59}$ Thus, the question once again arises; what is a hedge fund and how should they be distinguished from these entities?

There are major problems with the definitions of a hedge fund and private equity fund set out in the Investment Company Act, as amended by the Private Fund Act, and the Volcker Rule. The first and foremost is that these definitions are both over- and under-inclusive: the Volcker Rule's prohibitions might include funds that were not intended to be regulated thereunder. In other words, not all investment funds traditionally considered to be hedge funds or private equity funds rely on the exemptions of sections 3(c)(1) or 3(c)(7) of the Investment Company Act. While it is possible to create an investment fund that relies on other exemptions provided by the Investment Company Act and do not literally fall under the definition of a hedge fund or private equity fund, such funds may pursue exactly the same strategies used by hedge funds and private equity funds, and those funds might not be captured by the Volcker Rule's definitions. For example, commodity pools that do not mainly invest in financial instruments can fall into this category of funds.

The definition's under-inclusiveness is partly addressed by the congressional grant of authority to regulators to bring 'similar funds' within the scope of the Volcker Rule. ${ }^{60}$ To determine which funds should be included in the category of 'similar funds', regulators should analyze the investment activities and other features of such funds, including their compensation structure, trading and investment strategy, use of leverage, and investor composition. ${ }^{61}$ Indeed, the Investment Company Act's statutory exemptions were not intended to exclusively apply to hedge funds and private equity funds. Thus, the criteria for delineating the exceptions the Volcker Rule intends to grant for certain funds remain to be determined by future rule making. The potential challenge to these definitions is that they provide excellent opportunities for legal engineering to circumvent them - that is, they are ripe for regulatory arbitrage. ${ }^{62}$ Likewise, hedge fund regulation, which relies on definitions with an appeal to the literal meaning of words through adjudication and judicial interpretation, can be used to undermine the very purpose of the regulation: to address the potential risks originating from the hedge fund industry. The section demonstrates that hedge fund regulation in the EU is not significantly different from that in U.S.; it is also over- and under-inclusive and susceptible to regulatory arbitrage.

\footnotetext{
${ }^{59}$ Council, Study \& Recommendations on Prohibitions on Proprietary Trading \& Certain Relationships with Hedge Funds and Private Equity Funds

${ }^{60} \mathrm{Ibid}$

${ }^{61}$ Ibid

${ }^{62}$ McBarnet, 'Financial Engineering or Legal Engineering? Legal Work, Legal Integrity and the Banking Crisis'
} 


\section{The Definition of hedge funds in the $\mathbf{E U}$}

The EU's Alternative Investment Fund Managers Directive (AIFMD) ${ }^{63}$ classifies hedge funds, along with several other funds, as 'Alternative Investment Funds' (AIFs). The AIFMD generally defines an AIF as any collective investment scheme that is not already covered by the regulatory regime established pursuant to the EU's Undertakings for Collective Investments in Transferable Securities (UCITSs) Directive (Directive 2009/65/EC (as amended by the Directive 2014/91/EU). More specifically, under the AIFMD, an AIF is any collective investment undertaking that raises capital from a number of investors with a view to investing it in accordance with a defined investment policy for the benefit of those investors and that does not otherwise require authorization pursuant to Article 5 of the UCITS Directive, as amended. ${ }^{64}$

As regulatory definitions are the most likely provisions used in regulatory arbitrage (e.g., purposely arranging the fund structure to avoid falling within the definition), the AIFMD attempts to address, at least in part, the issue in its definitional sections involving its scope and application. Thus, the AIFMD's first line of defense against regulatory arbitrage by hedge funds or other investment vehicles, is embedded in its definitional sections: it does so by creating a very broad definition of an AIF that tries to capture all non-UCITS, to close potential loopholes, and to mitigate the risk of regulatory arbitrage. ${ }^{65}$

After the AIFMD's enactment, investment funds established in Europe are generally classified into two broad categories: UCITSs and AIFs. The UCITS category includes, among others, mutual funds and pension funds regulated under the UCITS Directive which are available to retail investors. Non-UCITSs or AIFs include, among others, hedge funds, private equity funds, and real estate funds, all of which are governed by the AIFMD. Its AIF definition, which is primarily intended to capture hedge funds and private equity funds, rules out many of the other considerations relating to the investment funds structure, such as the organizational form of a fund (i.e., open-ended or close-ended) ${ }^{66}$ and its legal and contractual form. ${ }^{67}$ In addition, the

\footnotetext{
${ }^{63}$ Directive 2011/61/EU of the European Parliament and of the Council of 8 June 2011 on alternative investment fund managers and amending Directives 2003/41/EC and 2009/65/EC and Regulations (EC) No 1060/2009 and (EU) No 1095/2010 (OJ L 174, 1.7.2011, pp. 1-73)

${ }^{64}$ Articles 4(1)(a) and 3 of the Directive 2011/61/EU. With respect to the scope, the AIFMD covers all EU managers managing EU and non-EU funds, non-EU managers managing EU funds, non-EU managers marketing EU or nonEU funds in the EU. Article 2(1) of the Directive 2011/61/EU

${ }^{65}$ Thomas M. J. Möllers, Andreas Harrer and Thomas C. Krüger, 'The AIFM Directive and Its Regulation of Hedge Funds and Private Equity' (2011) 30 Journal of Law and Commerce 8791 In addition to hedge funds directly regulated by the Directive, the Directive also regulates the relationship of the prime brokers and AIFMs (indirect regulation of hedge funds) therefore; it has implications for the business of these firms as well.

${ }^{66}$ In its initial draft, the AIFMD did not include the close-ended funds, while in the adopted version it covers all of them. See ibid

${ }^{67}$ Recital 3 of the Directive 2011/61/EU states that many AIFM's strategies are prone to risks in relation to inventors, other market participants and markets. Therefore, to provide comprehensive arrangement for supervision, the establishment of a framework for addressing those risks by taking into account the diverse range of AIFMs' strategies and techniques is necessary. To provide such all-encompassing framework, recital 3 of the Directive emphasizes that the "Directive should apply to AIFMs managing all types of funds that are not covered by Directive 2009/65/EC of the European Parliament and of the Council of 13 July 2009 on the coordination of laws, regulations
} 
AIFMD applies regardless of the nature of the fund's investment strategies. ${ }^{68}$ Although the AIFMD does not differentiate between public and non-public (private) marketing, ${ }^{69}$ one UCITS feature that clearly distinguished a UCITS from an AIF is its source of capital: UCITSs raise capital from the public, whereas AIFs raise their capital privately. ${ }^{70}$ Access to AIFs is, therefore, often restricted to professional investors. ${ }^{71}$

Despite the AIFMD's sweeping, and seemingly over-inclusive, regulation, it explicitly excludes: holding companies; institutions for occupational retirement provision, which are already covered by the EU Directive on the Activities and Supervision of Institutions for Occupational Retirement Provision; supranational institutions; ${ }^{72}$ national central banks; national, regional, and local governments; bodies or institutions managing funds that support social security and pension systems; employee participation or employee savings schemes; and securitization special purpose entities. ${ }^{73}$

It seems that the AIFMD's attempt to mitigate the risks of regulatory arbitrage compromises the exclusiveness criterion of its definitions; by trying not to expose its provisions to regulatory arbitrage, the EU opted for broad and over-inclusive definitions. Not surprisingly, even before its implementation, the industry and many commentators criticized the AIFMD's overbroad definition of an AIF. ${ }^{74}$ For example, there is considerable uncertainty as to whether certain legal entities and structures fall within the its scope. Such concerns are particularly pronounced regarding products such as covered bonds, acquisition vehicles, managed accounts, and indexlinked or performance notes. ${ }^{75}$

A second criticism of the sweeping definitions contained in the AIFMD, is that it captures a broad array of dissimilar funds with highly heterogeneous investment strategies and indiscriminately regulates them as if they were identical. Indeed, one of the significant recurring concerns raised throughout the AIFMD's legislative process was that its one-size-fits-all

and administrative provisions relating to the undertakings for collective investment in transferable securities (UCITS) (4), irrespective of the legal or contractual manner in which the AIFMs are entrusted with this responsibility. AIFMs should not be entitled to manage UCITS within the meaning of Directive 2009/65/EC on the basis of an authorisation under this Directive." See Recital 3 of the Directive 2011/61/EU.

${ }^{68}$ Angus Duncan, Edmond Curtin and Marco Crosignani, 'Alternative regulation: the directive on alternative investment fund managers' (2011) 6 Capital Markets Law Journal 326335

${ }^{69}$ Möllers, Harrer and Krüger, 'The AIFM Directive and Its Regulation of Hedge Funds and Private Equity'

${ }^{70}$ Duncan, Curtin and Crosignani, 'Alternative regulation: the directive on alternative investment fund managers'

${ }^{71}$ Unlike the pre-crisis regulatory framework, in the new regulations, there is no differential regulatory treatment of funds based on their marketing to different categories of investors. See Möllers, Harrer and Krüger, 'The AIFM Directive and Its Regulation of Hedge Funds and Private Equity'

${ }^{72}$ Such as "the European Central Bank, the European Investment Bank, the European Investment Fund, the European Development Finance Institutions and bilateral development banks, the World Bank, the International Monetary Fund, and other supranational institutions and similar international organisations, in the event that such institutions or organisations manage AIFs and in so far as those AIFs act in the public interest".

${ }^{73}$ Article 2(3) of the Directive 2011/61/EU

${ }^{74}$ Phoebus Athanassiou, 'The AIFM Directive: An Overview of the Final Rules' (2011) 26 Journal of International Banking Law and Regulation 237242

${ }^{75}$ Ibid 
approach $^{76}$ did not work well for all the different types and sizes of AIFs and their managers. Moreover, it was argued that such an approach could fail to differentiate, and draw a distinct line, between the different types of risk arising out of different types of funds and their managers. ${ }^{77}$

Although the European Parliament ostensibly believed that the AIFMD would cover all small funds, it proposed a differentiated approach to regulating the industry, based on the types of funds rather than a uniform-but-sweeping one-size-fits-all regulatory approach. ${ }^{78}$ Nevertheless, despite the fact that some of the AIFMD's provisions attempt to differentiate between large hedge funds and smaller ones and to draw a line between hedge funds, on the one hand, and private equity funds, particularly venture capital firms, on the other, the provisions ultimately adopted generally fail to differentiate between different types of hedge funds based on their investment strategies. ${ }^{79}$ For example, certain regulatory issues are more relevant to hedge funds and less relevant to private equity funds. To be more specific, maturity transformation, which may be relevant to the hedge fund industry, is not relevant to private equity funds, ${ }^{80}$ which implies that liquidity requirements for hedge funds should be different from those for private equity funds. ${ }^{81}$ Moreover, concerns about leverage in hedge funds and private equity funds are different: hedge fund leverage occurs at the fund level, both directly and indirectly, through off-balance sheet exposure (e.g., investment in derivatives), while private equity fund leverage often occurs at the portfolio company level. ${ }^{82}$ When regulating hedge funds, it is imperative that adequate attention be paid to the heterogeneity of funds, particularly hedge funds, because

\footnotetext{
${ }^{76}$ Such a one-size-fits-all approach is similar to the approach followed by the Australian Commonwealth Corporations Act 2001 in which a single licensing regime for financial products is in place which includes, among other alternative investment products, hedge funds. See Giorgio Tosetti Dardanelli, 'Direct or Indirect Regulation of Hedge Funds: A European Dilemma' (2011) European Journal of Risk Regulation 463475

${ }^{77}$ Eilís Ferran, 'After the Crisis: The Regulation of Hedge Funds and Private Equity in the EU' (2011) 12 European Business Organization Law Review 379398

${ }^{78}$ See ibid

${ }^{79}$ As discusses earlier, for some hedge funds proprietary information is more central than for others. The value of such information for hedge funds depends on what strategies they specialize in. Some hedge funds are not willing to disclose information even at the expense of more investments or receiving better credit terms. See Roger T. Cole, Greg Feldberg and David Lynch, 'Hedge Funds, Credit Risk Transfer and Financial Stability' in France Banque de (ed), Financial Stability Review; Special Issue, Hedge Funds (Financial Stability Review; Special Issue, Hedge Funds, 2007) 11

${ }^{80}$ Payne, 'Private Equity and Its Regulation in Europe'

${ }^{81}$ The AIFMD differentiates hedge funds from private equity funds and especially venture capital fund by a fiveyear redemption restriction criterion.

${ }^{82}$ To differentiate further between private equity and hedge funds it is noteworthy to highlight that hedge funds trade in almost all financial instruments, assets and commodities, while private equity funds often invest in equities. In addition, the risk of counterparty is less in private equity compared to hedge funds. It is also argued that hedge funds' trading strategies are highly correlated while the heterogeneity of assets in private equity implies that it is unlikely that the fire sale externalities might occur due to strategy correlations. The only systemic risk related issue that can occur in private equity funds rises from the input of bank debt into the portfolio company, however, the AIFMD does not seem to be addressing such an issue. See Payne, 'Private Equity and Its Regulation in Europe' Nevertheless, except under very limited circumstances, the AIFMD almost invariably treats these institutions as if they are identical in every aspect.
} 
of their differences from similar investment companies and the need for differentiation in regulating such heterogeneous entities.

In light of the above discussion, it seems that the AIFMD's attempt to uniformly regulate AIFs and capture all possible contingencies largely overlooks significant differences between AIFs, strategies, and instruments, all of which require differentiated regulatory treatment. In other words, the AIFMD's strategy for preventing regulatory arbitrage and circumvention of its provisions went too far. Most hedge fund managers believe that the AIFMD's one-size-fits-all regulatory approach is highly inappropriate and, for at least some hedge funds, its regulations "simply do not make sense." 83

With regard to systemic-stability issues, the differentiation between different-but-seemingly similar funds is of special significance. Regulators must devise benchmarks to differentiate and separate systemically important hedge funds from other funds that do not pose systemic threats to the financial system. For example, the Dodd-Frank Act, mentioned above, contains rules for identifying and regulating the potential systemic risk of private funds (including hedge funds) by assigning responsibility for designating entities as Systemically Important Nonbank Financial Companies (SINBFCs) to the Financial Stability Oversight Council (FSOC). The Dodd-Frank Act grants authority to the FSOC to determine whether a non-bank financial company (which includes, among others, hedge funds) is to be supervised by the Federal Reserve (the Fed) and be subject to prudential standards. If the FSOC determines that "material financial distress at the U.S. nonbank financial company, or the nature, scope, size, scale, concentration, interconnectedness, or mix of the activities of the U.S. nonbank financial company, could pose a threat to the financial stability of the United States", it will subject the company to the Fed's prudential supervision. ${ }^{84}$ Furthermore, the FSOC has been given the discretion to recommend to the Fed that it strengthen the prudential standards for a particular SINBFC. ${ }^{85}$ In the EU, however, although the AIFMD introduces lower benchmarks to exclude smaller AIFMs from its regulatory requirements, when compared with the Dodd-Frank Act, the criteria for designating individual hedge funds as systemically important AIFs are blatantly absent.

The EU- and the U.S.-regulatory approaches to tackling regulatory arbitrage by hedge funds are ill-suited for such a purpose. The remainder of this Article argues that, although all attempts to forestall regulatory arbitrage are flawed, the least-flawed method for tackling regulatory arbitrage is neither offering a negative definition nor a restrictive or over-inclusive definition;

\footnotetext{
${ }^{83}$ Mats Persson, The EU's AIFM Directive: Likely Impact and Best Way Forward, , 2009)

${ }^{84} 12$ U.S.C. $\$ 5323$ (a)(1)

${ }^{85}$ Lloyd, Clancy and Kumar, Hedge Funds and Systemic Risk
} 
rather, the least-flawed method involves opting for a different regulatory strategy: principlesbased regulation. After examining that regulatory strategy, the Article contends that the U.S. regulatory strategy, which affords regulators discretion to identify hedge funds, can be more effective in the fight against regulatory arbitrage arising from definitional problems. But, before offering regulatory strategies to fight definitional problems, the following section explains how hedge funds might take advantage of definitional problems to circumvent regulations and game regulatory regimes.

\section{Definitional problems and regulatory arbitrage}

One of the main sources of legal engineering and regulatory arbitrage is definitional problems in the regulation itself. ${ }^{86}$ Regulatory arbitrage ${ }^{87}$ essentially "exploits the gap between the economic substance of a transaction and its legal or regulatory treatment". ${ }^{88}$ Such exploitation is made possible due to a "legal system's intrinsically limited ability to attach formal labels that track the economics of transactions with sufficient precision". ${ }^{89}$ Thus, definitional problems cause regulatory complications and attempts to define hedge funds for regulatory purposes are no exception. For years, initiatives to tighten hedge fund regulation have been thwarted by an inability to define them properly.

In addition to the inherent indeterminacy in language, ${ }^{90}$ the prospective generalizations that are a necessary feature of law ${ }^{91}$ are yet another source of indeterminacy and vagueness in statutory definitions and subsequent interpretations. Regardless of how precise and determinate a

\footnotetext{
${ }^{86}$ McBarnet, 'Financial Engineering or Legal Engineering? Legal Work, Legal Integrity and the Banking Crisis'

${ }^{87}$ Regulatory arbitrage has different sources. This Article only focuses on the regulatory arbitrage opportunities that arise from definitional problems. In the European Union the dynamism of regulatory competition, which can create ample opportunities for regulatory arbitrage in company law, is slightly different from that of the U.S. This is because the theory adopted in major EU jurisdictions regarding the determination of applicable laws to companies differs from the theory adopted in the U.S.

There are two main contrasting theories regarding the applicable law to companies; the incorporation theory and the real seat theory. According to the incorporation theory, the laws of the jurisdiction in which the company is incorporated govern that company. In this view, the location of the business operations of the company does not matter. The incorporation theory is mainly adopted in the U.S. and allows for vast regulatory competition and regulatory arbitrage opportunities.

In contrast, under the real seat theory, the company is subject to the laws and regulations of the jurisdiction in which its main business activities are being undertaken (or where the headquarter of a firm is located). This theory is dominant in the EU. Although most European countries opted for the real seat theory, the EU Treaty and recent judicial developments of the European Court of Justice (ECJ) pave the way for regulatory competition in the EU. Article 48 of the Treaty on the Functioning of the European Union (TFEU) recognizes the right of establishment of undertakings. Furthermore, article 50 of the TFEU is concerned with the mutual recognition of companies. See also article 54 of the TFEU. See Marco Becht, Colin Mayer and Hannes F. Wagner, 'Where do firms incorporate? Deregulation and the cost of entry' (2008) 14 Journal of Corporate Finance 241

Although the initial arbitrage that has taken place in the wake of those decisions came to an end, scholars still believe that the EU should guarantee and promote regulatory competition. See Horst Eidenmüller, 'The Transnational Law Market, Regulatory Competition, and Transnational Corporations' (2011) 18 Indiana Journal of Global Legal Studies 707.

${ }^{88}$ Fleischer, 'Regulatory arbitrage'

${ }^{89}$ Ibid

${ }^{90}$ Hart, The Concept of Law

${ }^{91}$ Joseph Raz, The Authority of Law: Essays on Law and Morality (Oxford University Press 1979) 214
} 
particular rule is, the limits of human foresight implies that even the most definitive terms may become vague when applied to a situation that was not already contemplated when the rule was adopted: ${ }^{92}$ in that case, "a rule ... is only as good as its interpretation." ${ }^{93}$ Thus, the choice of a particular method of interpretation in financial regulation, enforcement, and adjudication can significantly affect the number and severity of problems arising from the boundaries set by statutory definitions in financial markets.

Limited linguistic ability, coupled with interpretation issues, breed opportunities in which technical compliance with the applicable rules and regulations can be achieved while undermining the underlying justifications on which the entire regulatory system or a specific law is predicated. Compliance of this sort, dubbed 'creative compliance', essentially involves "using the law to escape legal control without actually violating legal rules", ${ }^{94}$ and is a welldocumented phenomenon..$^{95}$

Aside from the intrinsic limited ability of legal systems to capture the substance and the economics of transactions, another source of regulatory arbitrage is associated with 'legal formalism'. Legal formalism - that is, denying the "necessity of choice in penumbral areas of rules" ${ }^{\prime 96}$ - follows the letter of a rule, even if it fails to serve its purpose. ${ }^{97}$ The emphasis on literal interpretation and legal formalism underscore the important role of definitions in legislation, rule-making, and adjudication. Needless to say, contrary to principles-based regulation, the focus of which is the 'goals' rather than the 'means' of achieving those goals, rules-based regulation creates vast opportunities for regulatory arbitrage. ${ }^{98}$ Likewise, rulesbased hedge fund regulation, along with the appeal to the literal meaning of words in adjudication and legal interpretation, can be used to undermine the very purpose of regulation designed to address the externalities of hedge funds.

Accordingly, the need for interpretation implies that the regulators' reliance on definitions is not necessarily helpful. On the contrary, it can be counterproductive. This impasse was the crux of the U.S. Court of Appeals for the District of Columbia Circuit decision in Goldstein v. SEC. ${ }^{99}$ In that case, Judge Randolph said, "[t]he lack of a statutory definition of a word does not

\footnotetext{
92 Julia Black, Rules and Regulators (Clarendon Press 1997)

${ }^{93}$ Ibid

${ }^{94} \mathrm{D}$. McBarnet and C. Whelan, 'The elusive spirit of the law: Formalism and the struggle for legal control' (1991) 54 Modern Law Review 848848

${ }^{95}$ See Karen Yeung, Securing Compliance: A Principled Approach (Hart Publishing 2004)

${ }^{96}$ Hart, The Concept of Law

${ }^{97} \mathrm{McBarnet}$ and Whelan define formalism as "a narrow approach to legal control - the use of clearly defined, highly administrable rules, an emphasis on uniformity, consistency and predictability, on the legal form of transactions and relationships and on literal interpretation." See McBarnet and Whelan, 'The elusive spirit of the law: Formalism and the struggle for legal control'

${ }^{98}$ McBarnet, 'Financial Engineering or Legal Engineering? Legal Work, Legal Integrity and the Banking Crisis'

${ }^{99}$ See Goldstein v. SEC, 451 F.3d 873, 884 (D.C. Cir. 2006).
} 
necessarily render the meaning of a word ambiguous, just as the presence of a definition does not necessarily make the meaning clear. A definition only pushes the problem back to the meaning of the defining terms." 100

Taking all the above-mentioned definitional problems into account, it is not surprising to observe a consistent tendency among hedge fund regulators to avoid engaging in definitional issues, especially issues concerning the hedge fund as an entity. ${ }^{101}$ The hassles associated with defining dynamic and heterogeneous entities, such as hedge funds, give rise to problems that make their regulation difficult, if not impossible, to implement. Indeed, the potential for regulatory arbitrage deters most regulatory attempts to define hedge funds and is a gigantic obstacle for rules-based regulation. These problems can better be addressed by using principlesbased regulation.

\section{A policy response to regulatory arbitrage}

The massive potential for hedge funds to practice regulatory arbitrage originates from rulesbased regulation and its inherent definitional problems. The alternative - principles-based regulation - is far better suited to combatting regulatory arbitrage. Principles-based regulation is, essentially, based on the standards-vs.-rules dichotomy in legal parlance. ${ }^{102} \mathrm{~A}$ beneficial aspect of 'standards' (as opposed to 'rules') is their flexibility; it allows regulated entities to choose the specific means of achieving the general standards and goals set by regulators, especially when regulation involves target and performance (or output) standards. ${ }^{103}$ Therefore, "in those areas of the law in which economic and social conditions change frequently and with them the optimal set of legal decisions, standards are more efficient than rules." 104

\footnotetext{
${ }^{100}$ A statement by Judge Randolph, Circuit Judge, in Goldstein v. SEC. See Goldstein v. SEC, 451 F.3d 873, 884 (D.C. Cir. 2006)

${ }^{101}$ Since the problem of definition is ubiquitous in regulation of economic activities and is not limited to the institution-based financial regulation, entity-based approach to regulation or institutional regulation has its own proponents. In other words, definitional problems also pose almost the same challenges to the 'product-based approach' to regulation. Gibson shows how regulation of swap agreements could escape regulation because there is uncertainty and complexities in defining financial products such as securities and futures. She concludes that concerning swap markets, the regulatory problems such as definitional and jurisdictional problems can best be addressed by focusing on the 'market participant-based regulation' rather than the classification of swap agreements as futures or securities. See Willa E. Gibson, 'Are swap agreements securities or futures?: The inadequacies of applying the traditional regulatory approach to OTC derivatives transactions' (1999) 24 Journal of Corporation Law 379416

With respect to hedge fund regulation, most regulations opted for an institutional one-size-fits-all regulation for 'alternative investment funds' or 'private funds'.

${ }^{102}$ See Louis Kaplow, 'Rules Versus Standards: An Economic Analysis' (1992) 42 Duke Law Journal 557

${ }^{103}$ Anthony Ogus, Regulation: Legal Form and Economic Theory (Hart Publishing 2004) 150

${ }^{104}$ Hans-Bernd Schaefer, 'Legal Rule and Standards' in Charles K. Rowley and Friedrich Schneider (eds), The Encyclopedia of Public Choice, Volume I (The Encyclopedia of Public Choice, Volume I, Kluwer Academic Publishers 2004) 348
} 
Although the feature of the 'rules' that eliminates the frequently recurring and unnecessary debate over the issues of value and fact is the factor that favors rules vis-à-vis standards, "because of their ex ante character, rules will usually be over-inclusive and under-inclusive with reference to the arguments that justify them," ${ }^{105}$ which is the price to be paid for the exante precision and specificity. ${ }^{106}$ Standards, on the other hand, are more durable, ${ }^{107}$ dynamic, and flexible, ${ }^{108}$ and less prone to regulatory arbitrage; ${ }^{109}$ when devising such a flexible approach, it is important to make use of standards rather than rules.

Needless to say, standard setting by means of target or output standards accommodates ex-post trade-offs and balancing different criteria; ${ }^{110}$ accordingly, it calls for market-participants' incentives and market discipline when crafting strategies to achieve the goals set by the standard-setter. For this reason, the former UK Financial Services Authority (FSA) ${ }^{111}$, prior to the financial crisis, relied on standards rather than rules in its financial regulation under 'principles-based regulation'. ${ }^{112}$

In the FSA's view, principles-based regulation meant "moving away from dictating through detailed, prescriptive rules and supervisory actions how firms should operate their business." 113 This regulatory strategy suggested "greater reliance on principles and outcome-focused, high level rules", and less reliance on prescriptive rules, to achieve certain regulatory outcomes. On this basis, the FSA emphasized the enhancement of a risk- and evidence-based approach to financial regulation with an eye toward outcomes. ${ }^{114}$

\footnotetext{
${ }^{105}$ Cass R. Sunstein, 'Problems with Rules' (1995) 83 California Law Review 9531022

${ }^{106}$ On the other hand, Sunstein, Cass R. (1995) argues that it is less likely that the rules result in judicial corruption. In addition, they are more protective of civil liberties and political rights than standards. See: ibid

${ }^{107}$ Isaac Ehrlich and Richard A. Posner, 'An economic analysis of legal rulemaking' (1974) 3 The Journal of Legal Studies 257277

${ }^{108}$ Schaefer, 'Legal Rule and Standards'

${ }^{109}$ McBarnet, 'Financial Engineering or Legal Engineering? Legal Work, Legal Integrity and the Banking Crisis'

${ }^{110}$ Pierre Schlag, 'Rules and Standards' (1985) 33 UCLA Law Review 379423

111 The UK FSA has been replaced by the Prudential Regulation Authority (PRA) and the Financial Conduct Authority (FCA).

${ }^{112}$ See Financial Services, Principles-based regulation: Focusing on the outcomes that matter

It seems that the FSA uses the term "principle" synonymous to the term 'standard'. This inference is best understood when they explicitly say that "Principles-based regulation means placing greater reliance on principles and outcomefocused, high level rules as a means to drive at the regulatory aims we want to achieve, and less reliance on prescriptive rules." Ibid and "For these reasons, we believe that further enhancing our risk-based and evidence-based approach to regulation with an increased emphasis on principles and outcomes is not only the right but also the only way to progress our regulatory regime." Ibid

However, the term 'principle' is used by Dworkin refers generically to 'principles' as 'the whole set of standards other than rules'. He further distinguishes between principles and policies. In its generic sense, it seems that the definition of principles conforms its being identical with the standards. However, in its specific sense, the standards per us, are policies per Dworkin, it is something beyond the scope of the thesis. For more information on this, see: Ronald Dworkin, Taking Rights Seriously (Harvard University Press 1978) 22

${ }^{113}$ Financial Services, Principles-based regulation: Focusing on the outcomes that matter

${ }^{114}$ Ibid However, as FSA argues, the detailed rules will not completely be eliminated. For example, in its view, the detailed rules are suitable where the effect of firms' behavior are not easily observable or only observable over a very long period of time, or where there is a need for consistency and standardization across an industry. For instance,
} 
There were, of course, costs and benefits to the FSA's approach. Firms benefitted from the flexibility of principles-based regulation and the role it may play in facilitating innovation and enhanced competition; the regulators benefitted from a flexible, facilitative role in innovation in regulatory methods and types of supervision, as well as enhanced regulatory competition. The FSA's approach likely resulted in durable regulation even in a fast-changing financial environment. All in all, it appears that all stakeholders benefitted from the purportedly improved conduct of firms focused more on substantive compliance than 'creative compliance'. ${ }^{115}$

In addition to the flexibility offered by principles-based regulation with regard to variations in details and implementation to achieve a particular goal and the opportunities that flexibility affords to achieving better regulatory international harmonization and decentralization, principles-based regulation contains a hidden aspect - that is, it can overcome legal engineering that tries to comply with the words of law while escaping its reach and undermining its spirit. Indeed, "principles-based regulation is seen as the only realistic response, the only way to try to capture the spirit of the law in the face of constant creativity and technical challenge." 116 The need to deal with legal and financial engineering to escape the spirit of law was the driving force behind the adoption of principles-based regulation by the Accounting Standards Board (ASB) in the 1990s, "which saw it as an essential bastion against opportunistic legal engineering". ${ }^{117}$

Notwithstanding the benefits associated with the FSA's approach, principles-based regulation came under criticism during the global financial crisis. Even the FSA called the approach a failure, partly because "a principles-based approach does not work with individuals who have no principles". ${ }^{118}$ However, after the financial crisis, scholars suggested the FSA and its successors not to abandon that regulatory approach merely because of crisis-driven criticism. ${ }^{119}$ These scholars warn that reverting to a rules-based approach will likely result in even more legal engineering. This result is highly plausible because, "creative compliance thrives on rulebased regulation, for tight specific rules provide particularly solid material for legal engineers

for the sake of easy comparability between different products, FSA may require detailed rules and define format and content for providing certain information. Ibid

${ }^{115}$ Julia Black, 'Forms and Paradoxes of Principles-based Regulation' (2008) 3 Capital Markets Law Journal 425 426

${ }^{116}$ McBarnet, 'Financial Engineering or Legal Engineering? Legal Work, Legal Integrity and the Banking Crisis'

${ }^{117}$ Ibid

${ }^{118}$ Hector Sants, Delivering Intensive Supervision and Credible Deterrence (2009)

${ }^{119}$ McBarnet, 'Financial Engineering or Legal Engineering? Legal Work, Legal Integrity and the Banking Crisis' See also Cristie L. Ford, 'Principles-based securities regulation in the wake of the global financial crisis' (2010) 55 McGill Law Journal 257273

And Dan Awrey, 'Regulating Financial Innovation: A More Principles-Based Proposal' (2011) 5 The Brooklyn Journal of Corporate, Financial \& Commercial Law 273 
to work with." ${ }^{120}$ Adherents of principles-based regulation steadfastly continue to call for a renewed commitment to it, as long as it is coupled with a meaningful enforcement and oversight. $^{121}$

Principles-based regulation can be more effective in preventing regulatory arbitrage than rulesbased regulation. A principles-based regulator needs to rely on a functional definition rather than a black-letter-law definition of a hedge fun, as the latter is prone to regulatory arbitrage. As demonstrated earlier, neither statutory nor case-law 'black-letter' definitions of hedge funds truly capture the nature and activities of the hedge fund industry; moreover, confining the scope of the definition of hedge funds to a negative definition tells nothing about the hedge fund industry itself. With principles-based regulation of hedge funds, the identification of real-world hedge funds by regulators and supervisors needs to be founded on a functional approach to the definition of hedge funds rather than a negative statutory definition. Since the current regulatory definitions of hedge funds do not reflect the true nature of the industry and its attributes, the following section of this Article defines hedge funds not by reference to what they are not, but by reference to what they are, what they do, and their 'specialness' in the grand scheme of financial markets and institutions.

\section{What is a hedge fund? An alternative definition}

Hedge funds, as one of many financial-market participants, play several roles with respect to intermediation, risk management, and allocation of funds. Despite their status as late-comer investment firms, they are at the forefront of the investment industry. Interestingly, hedge funds, like other mainstream investment companies, are collective investment vehicles that manage pools of securities on behalf of their investors; from a functional standpoint, hedge funds can hardly be distinguished from traditional investment companies.

From an etymological perspective, a 'hedge' is a mechanism designed to reduce risk. Although the first hedge fund was designed for hedging purposes, ${ }^{122}$ the reality of hedge funds is far removed from its etymological roots. In other words, the term 'hedge fund' does not necessarily imply that a particular fund is 'hedged' and, therefore, has limited exposure to underlying market risks. Indeed, it is hard to find a greater misnomer than the term 'hedge fund', because hedge funds more often speculate than hedge. ${ }^{123}$

\footnotetext{
${ }^{120}$ McBarnet, 'Financial Engineering or Legal Engineering? Legal Work, Legal Integrity and the Banking Crisis'

${ }^{121}$ Ford, 'Principles-based securities regulation in the wake of the global financial crisis'

${ }^{122}$ Loomis, 'The Jones nobody keeps up with'

${ }^{123}$ Franklin R. Edwards, 'Hedge funds and the collapse of long-term capital management' (1999) 13 Journal of Economic Perspectives 189189
} 
To better understand hedge funds, they must be viewed in light of their similarities with, and differences from, other financial institutions. In general, when compared to other mainstream financial institutions, hedge funds are more lightly regulated. Indeed, the first, and perhaps most significant, distinguishing characteristic of hedge funds, which contributes to their relative success, is the lack of legal and regulatory restraints on their investment strategies. Therefore, lighter regulatory treatment of hedge funds is one of their most significant distinctive features. The implications of this differentiated regulatory treatment are that they cannot sell their shares to the general public, and their pool of investors must be limited to certain institutional investors and high-net-worth individuals (HNWIs). In addition, since hedge funds' investment strategies and their concentration and liquidity policies are not restricted, they can engage in aggressive investment strategies to exploit certain short-term investment opportunities.

The second-most conspicuous difference is the hedge funds' organizational form and legal structure. Mutual funds, for example, generally use simple onshore organizational forms, whereas hedge funds often establish complex onshore and offshore structures. ${ }^{124} \mathrm{~A}$ second unique feature is that hedge funds are typically organized in the form of either limited liability partnerships (LLPs) or limited liability companies (LLCs). Such legal structures, which are often composed of limited partners (LPs) as well as general partners (GPs), allow for managerial co-investment in the fund. Managerial co-investment, in turn, can obviate agency problems, conflicts of interests between managers and investors, and the tendency of the funds' managers to engage in excessive risk taking.

The hedge fund industry's fee structure is a third idiosyncratic feature: it is unique in that, beyond the usual management fee that is charged on the overall investment in the fund, hedge funds often charge additional 'performance' or 'incentive' fees. While the amount of these fees differs, most hedge funds follow the ' 2 to 20 rule': they charge two percent of the investment in the fund as their standard management fee plus an incentive or performance fee equal to twenty percent of the funds' profits.

A fourth distinctive hedge fund feature is that they often limit their investors' redemption rights and, hence, investment in hedge funds is considered to be rather illiquid when compared to the liquidity that banks and mutual funds offer to their depositors and investors. Moreover, hedge funds can limit investor redemptions in unconventional ways by using gates and side-pocket

\footnotetext{
${ }^{124}$ Lhabitant, Handbook of Hedge Funds
} 
arrangements ${ }^{125}$ that are thought to be essential for liquidity management. ${ }^{126}$ Nevertheless, investments in hedge funds are often more liquid than investment in other AIFs, such as private equity and venture capital funds.

Searching for a definition that includes all aspects of hedge funds, while simultaneously excluding other financial institutions seems to be a futile endeavor; there is always a need for, at the very least, a working definition to pass through the definitional quagmire and take further steps in studying them. A working 'functional' definition of a hedge fund is: a privately organized ${ }^{127}$ investment vehicle with a specific fee structure, ${ }^{128}$ that is not widely available to the public, ${ }^{129}$ is aimed at generating absolute returns irrespective of market movements (alpha) ${ }^{130}$ through active trading, ${ }^{131}$ and makes use of a variety of trading strategies. Although this working 'functional' definition is not particularly helpful in identifying real-world hedge funds, the following description of the industry provides a better picture of hedge funds and unravels some of the myths associated with the hedge fund industry.

\section{Are hedge funds special?}

The working 'functional' definition presented above must be expanded and clarified because it is important to understand why hedge funds are special, what makes them different, and what they contribute to financial systems that other financial institutions do not. In other words, a

\footnotetext{
125 To prevent a run on hedge funds, hedge fund managers usually use a gate or a gate provision. Gate provisions are restrictions on hedge fund investors intended to limit the amount of withdrawals from the fund during a redemption period. Side pocket arrangements are referred to mechanisms to segregate parts of a hedge fund's assets to be invested in illiquid and hard to value projects or investments. The assets allocated to the side pockets cannot be redeemed unless the returns on the projects or investments are realized or they become liquid marketable securities again.

126 The above-mentioned parameters created a comparative advantage for hedge funds in comparison to the mainstream financial institutions. These features of hedge funds are the result of a labyrinth of regulatory and fundamental economic processes. That regulatory structure which gave rise to the hedge funds will be studied in detail in the fourth chapter, which deals with the hedge funds regulation in the U.S. prior to the financial regulatory reforms.

${ }^{127}$ Hedge funds are mainly structured in the form of a Limited Liability Partnership (LLP) or a Limited Liability Company (LLC).

${ }^{128}$ A typical hedge fund charges $2 \%$ of the net asset value under management as management fee and $20 \%$ of the profits as performance or incentive fee (certain high-water marks and hurdle rates may apply).

${ }^{129}$ In the U.S., the Jumpstart Our Business Startups Act (JOBS Act) directs the SEC to amend the rule 506 of regulation $\mathrm{D}$ to remove the ban on hedge fund general solicitation. However, the sale of hedge fund products is still restricted to the accredited investors. See 15 U.S.C. $\$ 77 d-1$.

${ }^{130}$ William A. Roach Jr, 'Hedge Fund Regulation- "What Side of the Hedges Are You on?' (2009) 40 The University of Memphis Law Review 165166

See also Andreas Engert, 'Transnational Hedge Fund Regulation' (2010) 11 European Business Organization Law Review 329333

${ }^{131}$ J. S. Aikman, When Prime Brokers Fail: The Unheeded Risk to Hedge Funds, Banks, and the Financial Industry (Bloomberg Press 2010) 60

In addition, investment in hedge funds is often illiquid and may only be redeemed intermittently. See ibid

Prior to Private Fund Act, the absence of registration requirement and legal restraints on their investment strategies were among the defining features of hedge funds. See United States and Exchange, Implications of the Growth of Hedge Funds: Staff Report to the United States Securities and Exchange Commission

See also Houman B. Shadab, 'The Law and Economics of Hedge Funds: Financial Innovation and Investor Protection' (2009) 6 Berkley Business Law Journal 240245
} 
true functional definition of hedge funds requires isolating hedge funds' idiosyncratic functions that, if hedge funds' did not exist, would, to a large extent, not be performed. For example, by law, taking deposits and granting loans are special functions performed by credit institutions and, in the absence of any authorized credit institutions, such functions would not be performed. Similarly, hedge funds perform a specific array of functions, which make them special among financial-market participants.

Around three decades ago, an argument was made that, because banks were special, they needed special regulatory treatment. ${ }^{132}$ Offering transaction accounts, providing backup liquidity for all other financial and non-financial institutions, and banks' role as a transmission belt for monetary policy were three features that distinguished banks from other financial and non-financial institutions. Almost two decades later, after recognizing the development of close substitutes for banks' services in the financial market, ${ }^{133}$ the same argument, with some slight variations, was repeated. ${ }^{134}$ Such an argument for banks' 'specialness' presupposes that, even taking into account the dynamic behavior of different classes of financial institutions, the financial services industry is, in fact, compartmentalized; ${ }^{135}$ the argument is based on the underlying assumption that the nature and function of financial institutions differentiate one financial institution from another. Therefore, due to their specialization in certain financial instruments and strategies, different financial institutions yield heterogeneous benefits, become subject to idiosyncratic risks, and inflict disparate risks to the financial system.

Likewise, that compartmentalization argument can be applied to support differential regulatory treatment for hedge funds. Such need for differential treatment can best be understood in light of the hedge funds' unique functions in the financial system and their potential costs and benefits for the financial markets. Indeed, hedge funds occupy a relatively sui generis position in financial markets and provide financial systems with 'special' and specific benefits that other financial institutions, given their functions and constraints, are unable to provide. ${ }^{136}$

Hedge funds provide diversification benefits for financial markets, ${ }^{137}$ which means that investing in hedge funds can improve the risk-return relationship for investors. In addition, during periods of negative-equity returns, investing in hedge funds can decrease the volatility

\footnotetext{
132 E. Gerald Corrigan, Are banks special?, 1982)

${ }^{133}$ See Alan J. Marcus, 'Deregulation and bank financial policy' (1984) 8 Journal of Banking \& Finance 557

${ }^{134}$ E. Gerald Corrigan, Are Banks Special?: A Revisitation (2000) However, other scholars do not agree with the 'specialness' argument for banks. For example, See Anat R. Admati and Martin Hellwig, The Bankers' New Clothes: What's Wrong with Banking and What to Do about It (Princeton University Press 2013)

${ }^{135}$ Richard S. Carnell, Jonathan R. Macey and Geoffrey P. Miller, The Law of Banking and Financial Institutions (4 edn, Aspen Publishers 2009) 60

${ }^{136}$ Needless to say, these sui generis functions are made possible first and foremost by the special regulatory treatment of hedge funds by the financial regulators.

${ }^{137}$ Wouter Van Eechoud and others, 'Future Regulation of Hedge Funds—A Systemic Risk Perspective' (2010) 19 Financial Markets, Institutions \& Instruments 269275
} 
of a portfolio by offsetting market movements. ${ }^{138}$ For example, allocating 10 to 20 percent of portfolio to alternative investments, which include hedge funds, is recommended as an ideal allocation of investments for pension funds that strive for a long-term low risk/low return investment strategy. ${ }^{139}$

Moreover, hedge funds are also sources of liquidity. ${ }^{140}$ Their liquidity function is especially pronounced in niche markets and during liquidity crises. ${ }^{141}$ By investing in sub-markets that are "less liquid, more complex and hard-to-value," such as convertible bonds, distressed debt, and credit default swaps markets, hedge funds can complete and deepen financial markets. ${ }^{142}$ In fact, the growth and development of some niche markets, such as unsecured and subordinated debt markets, in recent years is attributed to or correlated with the growth of hedge funds that are willing to take risks that other traditional financial firms, such as banks, are not. ${ }^{143}$

The hedge funds' focus on generating alpha, which comes from outperforming markets, is generally achieved by exploiting market imperfections and discrepancies. ${ }^{144}$ This hedge-fund function benefits financial markets because it facilitates and accelerates their price-discovery mechanism by eroding arbitrage opportunities. ${ }^{145}$ Furthermore, legal protections for their proprietary information induce hedge funds to invest in the acquisition of private information, which is virtually exempt from disclosure requirements; that investment enables hedge funds to spot and exploit mispriced assets and securities, which can eventually lead to more efficient markets by pushing the securities prices to their true or fundamental values. ${ }^{146}$ Moreover, their proprietary investment in information acquisition can significantly increase the hedge funds' role in disciplining underperforming firms ${ }^{147}$ and, in some cases, uncovering fraudulent activities. Therefore, the larger the number and size of hedge funds, the more efficient the financial markets become. ${ }^{148}$

\footnotetext{
${ }^{138}$ Thomas Schneeweis, Vassilios N. Karavas and Georgi Georgiev, 'Alternative Investments in the Institutional Portfolio' (2002) CISDM Working Paper Series

${ }^{139}$ William F. Sharpe, 'Asset allocation: Management style and performance measurement' (1992) 18 Journal of Portfolio Management 7

${ }^{140}$ See Robert J. Bianchi and Michael E. Drew, 'Hedge Fund Regulation and Systemic Risk' (2010) 19 Griffith Law Review 613 See also Francesco Franzoni and Alberto Plazzi, 'Hedge Funds' Liquidity Provision and Trading Activity' (2012)

${ }^{141}$ The provision of liquidity by hedge funds in niche markets became mostly possible because of the differential regulatory treatment applied to them in terms of the lack of limits on the amount of leverage, investment concentration, short selling, and use of structured products and derivatives.

${ }^{142}$ Eechoud and others, 'Future Regulation of Hedge Funds-A Systemic Risk Perspective'

${ }^{143}$ Bianchi and Drew, 'Hedge Fund Regulation and Systemic Risk'

${ }^{144}$ In fact, the lack of legal restrictions on hedge funds' use of financial instruments, strategies, and their investment concentration enables them to use a wide range of techniques to exploit market imperfections.

${ }^{145}$ Andrew Crockett, 'The Evolution and Regulation of Hedge Funds' in France Banque de (ed), Financial Stability Review; Special Issue, Hedge Funds (Financial Stability Review; Special Issue, Hedge Funds, 2007) 22

${ }^{146}$ Roach Jr, 'Hedge Fund Regulation- "What Side of the Hedges Are You on?'

${ }^{147}$ Lucian A. Bebchuk, Alon Brav and Wei Jiang, 'The Long-Term Effects of Hedge Fund Activism' (2013) SSRN Working Paper Series

${ }^{148}$ Crockett, 'The Evolution and Regulation of Hedge Funds'
} 
Due to their lighter regulation, it is somewhat easier for hedge funds to take contrarian positions in financial markets. Unlimited use of leverage, short selling, ${ }^{149}$ limited investor liquidity (limited redemption rights or longer lock-ups), unlimited ability to invest in derivatives, and unrestrained investment concentration all enable hedge funds to take positions in financial markets that other financial institutions cannot take because of their regulatory capital requirements. This contrarian function of hedge funds can smooth and reduce market volatility as well as reduce the number and volume of asset price bubbles. ${ }^{150}$ Not surprisingly, empirical evidence suggests that hedge fund leverage is countercyclical to the leverage of listed financial intermediaries, meaning that given the pro-cyclicality of leverage in other financial institutions, hedge fund leverage has an inverse relationship to the leverage of other major financial market participants. ${ }^{151}$ In other words, when mainstream financial institutions increase their leverage during a financial boom, the hedge fund leverage tends to decrease, whereas in a financial bust or credit crunch, the mainstream financial institutions' leverage decreases, while hedge fund leverage tends to increase. This hedge fund feature, coupled with their unlimited ability to leverage their contrarian positions, amplifies the effects of such positions. As a result, contrarian-position taking by hedge funds can smooth the volatility of financial markets. Indeed, the nature of hedge funds' contrarian strategies enables them to be active traders during financial crises, which can also potentially form a price floor in distressed markets. Other financial institutions, such as credit institutions, cannot play that role because they are all subject to risk-based capital-adequacy requirements (CARs). ${ }^{152}$ Therefore, hedge funds provide a significant stabilizing influence by providing liquidity and spreading risk across a broad range of investors. ${ }^{153}$

More importantly, the hedge fund-investor base and the mechanisms hedge funds use to lockup capital for longer periods allow them to sustain their contrarian positions against market perceptions and movements. ${ }^{154}$ Unlike mutual funds and banks, hedge funds are not obliged to redeem an investor's investment on demand or even within a very short period of time. The right to redeem alternative investments is typically governed by private contracts that are likely

\footnotetext{
${ }^{149}$ In order to take a short position, the trader usually borrows the securities from a dealer and sells them to the market with the expectation that price of the securities will be lower at certain point in the future at which the trader will again buy them back and return them to the dealer. By doing so, the short seller pockets the difference between higher sale price and lower purchase price at which he has bought them back and returned them to the dealer.

${ }^{150}$ Eechoud and others, 'Future Regulation of Hedge Funds-A Systemic Risk Perspective'

${ }^{151}$ This means that hedge funds can be liquidity providers in times of liquidity crunch. See Andrew Ang, Sergiy Gorovyy and Gregory B. van Inwegen, 'Hedge Fund Leverage' (2011) 102 Journal of Financial Economics 102 Their empirical study suggests that, unlike other financial institutions such as banks, hedge funds' leverage decreased prior to the start of the financial crisis.

152 Jón Daníelson and Jean-Pierre Zigrand, 'Regulating Hedge Funds' in France Banque de (ed), Financial Stability Review; Special Issue, Hedge Funds (Financial Stability Review; Special Issue, Hedge Funds, 2007) 30

${ }^{153}$ Jean-Pierre Mustier and Alain Dubois, 'Risks and Return of Banking Activities Related to Hedge Funds' (2007) Banque de France, Financial Stability Review; Special Issue, Hedge Funds 8588

${ }^{154}$ Crockett, 'The Evolution and Regulation of Hedge Funds'
} 
to impose longer lock-up periods on the investors' capital. In particular, gates and side-pocket arrangements within the purview of private ordering give hedge funds another tool to restrict investor liquidity. Freedom from liquidity constraints gives hedge funds even more tools and techniques to better manage their liquidity risks, enabling them to have long-term horizons in their investment strategies. ${ }^{155}$

Relying, in part, on such benefits, it has been argued that, since the emergence of hedge funds as major-market participants, the financial markets have become more resilient in times of market turbulence, such as the technology or dot-com bubble burst, the 2001-2002 recession, the 9/11 terrorist attacks, the Iraq and Afghanistan wars, and the shocks caused by corporate scandals. ${ }^{156}$ Although the severity of the recent global financial crisis and the collapse of a number of hedge funds generated significant doubts about that claim, evidence suggests that many new hedge funds were launched to take advantage of price dislocations in securitized markets. ${ }^{157}$

All in all, hedge funds can substantially contribute to "capital formation, market efficiency, price discovery, and liquidity". ${ }^{158}$ Regulatory agencies have consistently acknowledged the benefits of hedge funds to financial system. ${ }^{159}$ Even after the financial crisis, the International Organization of Securities Commissions (IOSCO) suggested that hedge funds should be compensated for their intermediary functions and willingness to take those risks that other financial market participants are unwilling (or unable) to take. ${ }^{160}$

Not only do the hedge funds' unique functions and benefits make them special in financial systems, thereby requiring special regulatory treatment, but also design-based ex-ante regulation of hedge funds justifies their differentiated regulatory treatment. By design, hedge funds have limits on the number and qualifications of their investor base. For example, investorbase limitations in existing hedge fund regulations rule out any further need for regulation to protect hedge fund investors. The same cannot be said for banks, mutual funds, pension funds,

\footnotetext{
${ }^{155}$ In terms of maturity transformation, hedge funds stand in between banks, mutual funds (with higher maturity transformation) on the one hand, and the pension funds, private equity funds and venture capital funds on the other hand. Despite arguments to the contrary, it seems that hedge funds play a limited role in liquidity transformation. See Eechoud and others, 'Future Regulation of Hedge Funds-A Systemic Risk Perspective'

However, it is suggested that recently hedge fund are engaging more and more in liquidity transformation. Payne, 'Private Equity and Its Regulation in Europe'

${ }^{156}$ Cole, Feldberg and Lynch, 'Hedge Funds, Credit Risk Transfer and Financial Stability'

${ }^{157}$ Lloyd, Clancy and Kumar, Hedge Funds and Systemic Risk

${ }^{158}$ Roach Jr, 'Hedge Fund Regulation- "What Side of the Hedges Are You on?'

${ }^{159}$ United States and Exchange, Implications of the Growth of Hedge Funds: Staff Report to the United States Securities and Exchange Commission

${ }^{160}$ Bianchi and Drew, 'Hedge Fund Regulation and Systemic Risk' In this perspective, the special regulatory treatment of hedge funds can be considered as a compensation package for hedge funds' benefits to the financial system such as liquidity provision in illiquid markets, helping the price discovery mechanism to become more efficient, risk distribution, contribution to financial integration, and diversification benefits.
} 
and insurance companies, because investors in those financial institutions are typically unsophisticated.

On the other hand, a hedge fund's choice of organizational form (LLP or LLC) automatically triggers certain mandatory rules relating to, among other things, the general partners' (or managers') co-investment in hedge funds and their potential liability. These features are intended to substantially align the fund manager's incentives with the interests of the hedge fund's investors. If not circumvented, one way or another, that organizational form automatically rules out the need to impose on hedge funds the types of corporate governance standards that are normally required for banks and mutual funds.

To recapitulate, hedge funds provide several benefits to financial markets. They are sources of diversification and liquidity. By investing in "less liquid, more complex and hard-to-value" markets such as convertible bonds, distressed debt, and credit default swaps markets, hedge funds complete and deepen financial markets. ${ }^{161}$ More importantly, their focus on generating alpha is rooted in exploiting market imperfections and discrepancies, ${ }^{162}$ which facilitates the price discovery mechanism in financial markets by eroding arbitrage opportunities. ${ }^{163}$ In addition, hedge funds are considered contrarian position-takers in financial markets, ${ }^{164}$ and the mechanisms they use to lock-up their capital, such as investors' limited redemption rights, enable them to sustain such contrarian positions. ${ }^{165}$ That function alone can potentially decrease market volatility and reduce the number and magnitude of asset price bubbles. ${ }^{166}$

Focusing on these functional features of hedge funds, which constitute the definition of hedge funds, can help regulators to identify hedge funds and distinguish them from a variety of similar investment firms. Although there can be no bullet-proof definition of hedge funds that includes all hedge funds but excludes all similar investment funds, this definition, which focuses on essential features and specific functions of the hedge fund industry in the financial market, represents a step forward in the policy responses aimed at regulating hedge funds. It is worth highlighting that, if applied rigidly, this definition, in itself, will not impede regulatory arbitrage and other problems arising out of definitions. However, when combined with a flexible approach within a principles-based regulation framework, this definition may provide helpful guidance to regulators attempting to identify and distinguish hedge funds from similar funds.

\footnotetext{
${ }^{161}$ Eechoud and others, 'Future Regulation of Hedge Funds-A Systemic Risk Perspective' See also Bianchi and Drew, 'Hedge Fund Regulation and Systemic Risk'

${ }^{162}$ In fact, the lack of legal restrictions on the use of financial instruments, strategies, and investment concentration of hedge funds enables them to use a wide range of techniques to exploit market imperfections.

${ }^{163}$ Crockett, 'The Evolution and Regulation of Hedge Funds' See Roach Jr, 'Hedge Fund Regulation- "What Side of the Hedges Are You on?' See also Crockett, 'The Evolution and Regulation of Hedge Funds'

${ }^{164}$ Ang, Gorovyy and van Inwegen, 'Hedge Fund Leverage'

${ }^{165}$ Crockett, 'The Evolution and Regulation of Hedge Funds'

${ }^{166}$ Eechoud and others, 'Future Regulation of Hedge Funds-A Systemic Risk Perspective'
} 
Using the definition is highly likely to help optimize regulatory efforts by making them pointed and focused to a set of specific funds and, in turn, prevent unintended consequences and potential unintended disruptions in both markets and institutions due to regulatory gaps or overlaps stemming from ill-conceived definitions of hedge funds.

\section{Conclusion}

This Article reviewed regulatory definitions of hedge funds in two main hedge fund jurisdictions. It argued that, since statutory definitions are prone to regulatory arbitrage, principles-based regulation, which focuses on outcomes rather than the means of achieving those outcomes, coupled with significant regulatory discretion, is needed to counter the gaming of regulatory regimes by hedge funds. This regulatory approach contrasts with the existing rules-based regulation approach that relies on statutory definitions and tends to tie regulators' hands in dealing with regulated firms.

It further argued that, in applying principles-based regulation, regulators need to have a clear understanding of the idiosyncratic attributes of hedge funds and their functions in financial markets. This Article represents an attempt to offer the functional definition of hedge funds needed for a principles-based approach, which is based not only on their organizational and regulatory attributes, but also on the functions they perform and the roles they play in financial markets. It also argued that, in order to address boundary problems and regulatory arbitrage, regulators should be granted the discretion necessary to designate investment funds as hedge funds based on their functions, investment strategies, and other essential attributes, regardless of a particular firm's legal or official label. Otherwise, relying on black-letter laws or definitions would lead to regulatory arbitrage that would undermine hedge fund regulation. The working 'functional' definition offered in this Article is intended to help regulators identify hedge funds and to avoid problems arising from a strictly legalistic hedge fund definition. 